\title{
Increasing The Learning Achievement Of Indonesian History, in Indonesia Nation Efforts Facing The Nation Disintegration through The Team Quiz Plus Method Outcomes
}

\author{
Gigieh Roessajanto \\ SMKN 12 Surabaya \\ e-mail: rgigieh@yahoo.com
}

\begin{abstract}
The purpose of this study was to determine the improvement of student learning achievement in learning Indonesian History in the material "The Efforts of the Indonesian Nation to Face National Disintegration through the Team Quiz Plus Method ". This research is a classroom action research in the X Multi Media 3 class of SMKN 12 Surabaya which was conducted in 3 cycles. Cycles 1, 2 and 3 each consist of 2 face-to-face meetings. Each cycle includes the stages of planning, action, observation, and reflection. The technique of collecting data is done by the method of observation and documentation. The instruments of data collection used are: 1) formative test questions; 2) student observation sheet. The results showed that the application of the Team Quiz Plus method proved to be able to improve student learning achievement in Indonesian History subjects in the material "The Efforts of the Indonesian Nation to Face National Disintegration".
\end{abstract}

Key words : Learning achievement, Team quiz plus method

\section{INTRODUCTION}

In the curriculum of the class X 2013, about History of Indonesia, there are areas of study that studied the chapter on "The efforts of the Indonesian Nation Disintegration Facing the Nation". The material discussed in the chapter began the beginning of Indonesian independence which was marked by many rebellions against the legitimate government such as the DI / TII rebellion, 1948 PKI Madiun, PRRI, PERMESTA, Andi Azis, RMS, G30S / PKI 1965, etc. which were quite numerous. Many students find it difficult and feel bored studying the material because there are so many names of rebellion, many rebellion locations, many names of leaders of rebellion, government efforts to overcome the rebellion, and the impact is also wide.

Student achievement in class X Multi Media 3 in the even semester of the 20182019 academic year in the field of study of Indonesian History in the chapter : "The Efforts of the Indonesian Nation to Face National Disintegration", are not good, many students are passive in the learning process. ask or answer questions from the teacher and there is no response to the lesson. At the end of the lesson the teacher had held a formative test in the X Multi Media 3 class, but the result was only 10 students who reached the Minimum Completeness Criteria (KKM) or only $28.6 \%$ of students achieved the agreed Minimum Completeness Criteria (KKM) score of 75. While 25 students scored under the Minimum Completeness Criteria (KKM) or 71, 4\% of students score under Minimum Completeness Criteria (KKM). Whereas in other class X more or less almost the same. This condition is very alarming considering that Indonesian History lessons on the topic are not too difficult but it turns out that student learning outcomes are not satisfactory.

The researcher tried to identify the problems that occurred in the X Multi Media 3 class, namely: (1) Many students were less interested in Indonesian History lessons in 
the material "The Efforts of the Indonesian Nation to Face National Disintegration." (2) Many students lack enthusiasm to follow the learning process. (3) Many students feel bored learning the names of rebellion, their leaders, their years, the government's efforts to make them happen, and their effects (3) Students' learning achievement is low. (4) The method used by researchers at that time was that question and answer turned out to be less successful in helping students achieve learning completeness.

The researcher tried to conduct introspection and discussion with fellow Indonesian History teachers at Surabaya 12 Vocational High School about why students were less active, lacking enthusiasm and the learning outcomes of X Multi Media 3 students were not good enough. Then we conclude that we need to try to improve so that our teaching methods are in accordance with Government Regulation No. 19 of 2005, Article 19 Paragraph 1 Government Regulation Number 19 of 2005, Article 19, paragraph 1 states that the learning process in educational units is held interactively, inspirational, fun, challenging, motivating students to actively participate, and providing sufficient space for initiative, creativity, according to the talents, interests, and physical and psychological development of students. Then the researcher made a learning plan by trying to apply the Team Quiz Plus method. With the use of such methods students are expected to lebi h the spirit of learning, so that the bell of teaching students to be better.

The method of Team Quiz Plus was chosen by researchers because in the steps of implementing the method students will inevitably cooperate in groups, will actively answer questions, and will be more enthusiastic to become a quiz winning team.

The problems that I want to study are: (a) Is the use of the Team Quiz Plus method able to increase learning activities of Indonesian History in Multi Media X class 3 students of Surabaya 12 Vocational High School especially on the material: "Efforts of the Indonesian Nation to Treat Nation Integration" (b) What method use The Quiz Plus team can improve the learning outcomes of Indonesian History students in class X Multi Media 3 on the material.

The objectives of this study are: (a) To find out whether the use of the Team Quiz Plus method can increase the learning activities of Indonesian History in the X Multi Media 3 class of Surabaya 12 Vocational High School on the material "The Efforts of the Indonesian Nation to Face National Disintegration ". (b) To find out whether the use of the Team Quiz Plus method can increase the learning history of Indonesian X Multi Media 3 students on this topic.

The benefits of this study are (1) For teachers, the results and findings of this study can provide information on whether learning Indonesian History using the Team Quiz Plus method can improve the activities and learning achievements of Indonesian History in the material "Efforts of the Indonesian Nation to Deal with National Disintegration ". (2) For schools, schools can make appropriate policies in an effort to improve student learning achievement in Indonesian History subjects. (3) For students, can increase learning motivation and learning achievement in achieving learning goals. (4) For the world of education, in general can contribute ideas to the history teacher.

Learning achievement is a result that has been achieved by students in their learning activities (from what has been done, done, etc.), as explained in the Large Dictionary of Indonesian Language (1995: 787). From this understanding, the learning outcome is the mastery of knowledge or skills developed by the subject, the level of which is indicated by the value of the test or the number of values given by the teacher. 
The method of the Team Quiz Plus is one type in the Active Learning learning method that serves to liven up the learning atmosphere, enable students to ask questions and answer and improve the ability of students to responsibility for what they learn in a fun and not boring way.

The Team Quiz learning method was developed by Mel Silberman. Active learning methods Team Quiz types will help students understand the subject matter. In the teaching and learning process by using active learning methods of the Team Quiz type, students together with their team study the material in worksheets, discuss material, give direction to each other, give questions and answers to each other. Students not only listen to information from the teacher, but also see what is explained by the teacher and do the test directly, so students do not easily escape and understand the material.

Silberman (2007: 58) reveals the procedures for learning using Team Quiz types are as follows:

1) The teacher chooses a topic that can be presented in three parts.

2) Students are divided into 3 teams.

3) The teacher explains the learning scenario.

4) The teacher presents the subject matter.

5) The teacher asks team A to prepare a short answer quiz, while teams B and C use the time to check their notes.

6) Team A gives quiz to team $B$. If team $B$ cannot answer the question, team $C$ is given the opportunity to immediately answer it.

7) Team A continues to the next question to $C$ team members and repeat the process.

8) When the quiz is finished, continue with the second part of the lesson and point team $\mathrm{B}$ as the quiz leader.

9) After team B completes the exam, continue with the third part and determine team C as the quiz leader.

But in learning in Multi Media X class 3 Surabaya 12 Vocational High School the writer tried to implement the Team Q uiz method in a form that was slightly different from the procedure that had been submitted by Silberman so that the writer gave the name Team Quiz Plus method. The difference is: we divide students into 7 groups because the number of students in class X Multi Media 3 is 35 people. Another difference is that each group is asked to make 10 questions then collected to the teacher. The teacher will read the quiz questions. The group that can answer, sounds a jolt first. If the correct answer gets a value of 100. If the answer is wrong, minus 50. At the end of the quiz, the group that gets the highest score gets a prize from the teacher.

\section{RESEARCH METHODS}

This research is an action research. Action research is a form of study that is systematically reflective by the perpetrators of actions to improve the conditions of learning carried out. (Mukhlis, 2000: 5).

In this action study using a form of collaborative action research, the person in charge of the full research was researchers assisted by the Indonesian History teacher team who were members of the Indonesian History the school subject teacher consortium (MGMPS) Surabaya 12 Vocational High School. This research took place at Surabaya 12 Vocational High Schools, precisely in the X Multi Media 3 class. The address of this school is 1st Siwalan Kerto Permai Surabaya, East Java. This research was conducted in March to April even semester of the school year 2018-2019. The 
research subjects were students of X Multi Media class 3 of Surabaya 12 Vocational High School with the number of students 35 people on the material: "Efforts of the Indonesian Nation to Face National Disintegration".

The research that the authors did was using Classroom Action Research (CAR) which used an action research model from Kemmis and Taggart (in Sugiarti, 1997: 6), which was spiral from one cycle to the next. Each cycle includes planning, action, observation, and reflection. The steps in the next cycle are revised plans, actions, observations, and reflections. Before entering the first cycle, preliminary actions were taken in the form of identifying problems.

The instruments used in this study consisted of: formative test questions and student activity observation sheets. The observation sheet is used by observers to observe the process of teaching and learning activities from the beginning of the lesson until the end of the lesson. The results of this observation can be used to find out whether students are really active during the learning process. This formative test is prepared based on the learning objectives to be achieved, used to analyze the ability to understand the concept of Indonesian History on the material: "The Efforts of the Indonesian Nation to Face National Disintegration".

Data collection techniques in this study are observations by observers (team of teachers who are not model teachers) regarding the activities of students and teachers, and documentation of the results of formative tests.

To analyze the success rate or percentage of student success after the teaching and learning process each round is done by giving an evaluation in the form of written test questions at the end of each round. This analysis is calculated using simple statistics, namely:

(1) To assess a test or formative test, the formula is used:

$$
\begin{aligned}
\bar{X}=\frac{\sum X}{\sum N} & \\
\mathrm{X} & =\text { average value } \\
\Sigma \mathrm{X} & =\text { Number of all student grades } \\
\Sigma \mathrm{N} & =\text { Number of students }
\end{aligned}
$$

(2) For completeness of learning

There are two categories of mastery learning, individually and classically. Based on the instructions for the implementation of teaching and learning curriculums of Indonesian History in SMK 12 Surabaya, namely a student has completed learning if he has achieved a score of $75 \%$ or a value of 75 , and the class is said to be complete if there are $85 \%$ who have achieved more than or equal to $75 \%$. To calculate the percentage of mastery learning the following formula is used:

$$
P=\frac{\sum \text { StudentsHad Re } a c h}{\sum \text { Students }} \times 100 \%
$$

\section{FINDING AND DISCUSSION}

\section{A. First Cycle}

a. Planning Phase 
At this stage the researcher was assisted by the school subject teacher consortium (MGMPS) team Indonesian History Surabaya 12 Vocational High School prepared learning tools consisting of lesson plans 1, formative test questions 1 , observation sheets, student chest numbers, media, and supporting teaching tools. This first cycle consists of 2 meetings each of 3 lesson hours per week.

b. Action and Observation Stage

The implementation of teaching and learning activities for cycles I was carried out in a class of 35 students. In this case the researchers as teachers of Indonesian history teacher while others joined the team of Indonesian History the school subject teacher consortium (MGMPS) as an observer. Observations are carried out simultaneously with the implementation of teaching and learning. This stage is divided into 3 parts, namely opening, core and closing. In the opening section, the researcher explains the learning objectives, then explains the learning methods that will be carried out that day, and apperception and motivation. In the Core section the researcher explained the outline of the material by displaying power points on the LCD screen about the PKI Madiun rebellion in 1948 and the DI / TII rebellion. Then the researcher explained the stages of the Team Quiz Plus method to be implemented, namely: (1) Students were divided into 7 groups, namely the Sumatra, Java, Kalimantan, Sulawesi, Bali, Maluku and Papua groups. (2) Each group receives a group worksheet in the form of a copy of the material and worksheet for making 10 questions. (3) . Each group received a hoax sound instrument. (4) Each group is asked to make encouraging yells. (5) Each group works together to study the material and make 10 questions, then it is collected to the teacher. (6) The quiz begins with group yells alternately. Then the teacher reads the quiz questions. The group that can answer sounds cheeky. If the correct answer gets 10 points 0 , and if wrong is reduced by 50. (7) At the end of the game, each group is asked to add the group value and write it on the board. The group with the highest score is 1,2 , and 3 gets the prize from the teacher.

After all students understand the procedures for Team Quiz Plus, the game Team Quiz Plus starts immediately. The researcher as a model teacher guides the quiz in front, while the observer observes the activities of students in groups.

From the results of the observations obtained descriptive data, namely:

Table 1. Assessment

\begin{tabular}{|c|c|c|c|c|c|}
\hline No. & $\begin{array}{l}\text { Group } \\
\text { name }\end{array}$ & Assessment Aspect & Well & Enough & Less \\
\hline 1 & Sumatra & $\begin{array}{l}\text { 1. Cooperation } \\
\text { 2. Sportsmanship } \\
\text { 3. Never give up } \\
\text { 4. Accuracy of } \\
\text { answers }\end{array}$ & & $\begin{array}{l}\mathrm{V} \\
\mathrm{V} \\
\mathrm{V} \\
\mathrm{V}\end{array}$ & \\
\hline 2 & Java & $\begin{array}{l}\text { 1. Cooperation } \\
\text { 2. Sportsmanship } \\
\text { 3. Never give up } \\
\text { 4. Accuracy of } \\
\text { answers }\end{array}$ & & $\begin{array}{l}\mathrm{V} \\
\mathrm{V} \\
\mathrm{V} \\
\mathrm{V}\end{array}$ & \\
\hline 3 & Borneo & $\begin{array}{l}\text { 1. Cooperation } \\
\text { 2. Sportsmanship } \\
\text { 3. Never give up } \\
\text { 4. Accuracy of } \\
\text { answers }\end{array}$ & & $\begin{array}{l}\mathrm{V} \\
\mathrm{V} \\
\mathrm{V} \\
\mathrm{V}\end{array}$ & \\
\hline
\end{tabular}




\begin{tabular}{|c|c|c|c|c|}
\hline 4 & Sulawesi & $\begin{array}{l}\text { 1. Cooperation } \\
\text { 2. Sportsmanship } \\
\text { 3. Never give up } \\
\text { 4. Accuracy of } \\
\text { answers }\end{array}$ & $\begin{array}{l}\mathrm{V} \\
\mathrm{V} \\
\mathrm{V} \\
\mathrm{V}\end{array}$ & \\
\hline 5 & Bali & $\begin{array}{l}\text { 1. Cooperation } \\
\text { 2. Sportsmanship } \\
\text { 3. Never give up } \\
\text { 4. Accuracy of } \\
\text { answers }\end{array}$ & & $\begin{array}{l}\mathrm{V} \\
\mathrm{V} \\
\mathrm{V} \\
\mathrm{V}\end{array}$ \\
\hline 6 & Maluku & $\begin{array}{l}\text { 1. Cooperation } \\
\text { 2. Sportsmanship } \\
\text { 3. Never give up } \\
\text { 4. Accuracy of } \\
\text { answers }\end{array}$ & $\begin{array}{l}\mathrm{V} \\
\mathrm{V} \\
\mathrm{V} \\
\mathrm{V}\end{array}$ & \\
\hline 7 & Papua & $\begin{array}{l}\text { 1. Cooperation } \\
\text { 2. Sportsmanship } \\
\text { 3. Never give up } \\
\text { 4. Accuracy of } \\
\text { answers }\end{array}$ & & $\begin{array}{l}\mathrm{V} \\
\mathrm{V} \\
\mathrm{V} \\
\mathrm{V}\end{array}$ \\
\hline
\end{tabular}

From the table of observations above, it can be seen that only 2 groups, namely the Sulawesi group and the Maluku group whose learning activities are good. While the other 5 groups are still not good.

At the end of the teaching and learning process students are given a formative test I with the aim of knowing the level of success of students in the teaching and learning process that has been carried out. The data from the research results in the first cycle are as follows:

Table 2. Formative Test Values in Cycle I

\begin{tabular}{|c|c|c|c|c|c|c|c|}
\hline \multirow{2}{*}{ No. } & \multirow{2}{*}{ Value } & \multicolumn{2}{|c|}{ Information } & \multirow{2}{*}{ No. } & \multirow{2}{*}{ Value } & \multicolumn{2}{|c|}{ Information } \\
\hline & & $\mathrm{T}$ & TT & & & $\mathrm{T}$ & TT \\
\hline 1 & 80 & $\sqrt{ }$ & & 19 & 60 & & $\sqrt{ }$ \\
\hline 2 & 50 & & $\sqrt{ }$ & 20 & 75 & $\sqrt{ }$ & \\
\hline 3 & 60 & & $\sqrt{ }$ & 21 & 75 & $\sqrt{ }$ & \\
\hline 4 & 75 & $\sqrt{ }$ & & 22 & 80 & $\sqrt{ }$ & \\
\hline 5 & 60 & & $\sqrt{ }$ & 23 & 75 & $\sqrt{ }$ & \\
\hline 6 & 80 & $\sqrt{ }$ & & 24 & 50 & & $\sqrt{ }$ \\
\hline 7 & 50 & & $\sqrt{ }$ & 25 & 75 & $\sqrt{ }$ & \\
\hline 8 & 75 & $\sqrt{ }$ & & 26 & 75 & $\sqrt{ }$ & \\
\hline 9 & 80 & $\sqrt{ }$ & & 27 & 60 & & $\sqrt{ }$ \\
\hline 10 & 50 & & $\sqrt{ }$ & 28 & 80 & $\sqrt{ }$ & \\
\hline 11 & 60 & & $\sqrt{ }$ & 29 & 75 & $\sqrt{ }$ & \\
\hline 12 & 70 & & $\sqrt{ }$ & 30 & 60 & & $\sqrt{ }$ \\
\hline 13 & 80 & $\sqrt{ }$ & & 31 & 75 & $\sqrt{ }$ & \\
\hline 14 & 75 & $\sqrt{ }$ & . & 32 & 80 & $\sqrt{ }$ & \\
\hline 15 & 70 & & $\sqrt{ }$ & 33 & 75 & $\sqrt{ }$ & \\
\hline 16 & 60 & & $\sqrt{ }$ & 34 & 85 & $\sqrt{ }$ & \\
\hline 17 & 60 & & $\sqrt{ }$ & 35 & 80 & $\sqrt{ }$ & \\
\hline 18 & 80 & $\sqrt{ }$ & & & & & \\
\hline total & 1215 & 8 & 10 & total & 1235 & 13 & 4 \\
\hline \multicolumn{8}{|c|}{$\begin{array}{l}\text { Ideal Maximum Score of } 3500 \\
\text { Total Score Achieved } 2450\end{array}$} \\
\hline
\end{tabular}


Table 3. Recapitulation of Formative Test Results of Students in Cycle I

\begin{tabular}{|l|l|c|}
\hline No. & \multicolumn{1}{|c|}{ Description } & Cycle I Results \\
\hline 1 & The average formative test value & 70 \\
2 & Number of students who complete study & 21 \\
3 & Percentage of learning completeness & $70 \%$ \\
\hline
\end{tabular}

From the table above, it can be explained that by applying the Team Quiz method, the average student achievement score is 70 and the learning completeness reaches $70 \%$ or there are 21 students from 35 students who have finished learning. These results indicate that in the first cycle classically students have not yet finished learning, because students who gain a value of $\geq 75$ are only $70 \%$ smaller than the desired percentage of completeness that is equal to $85 \%$. But these results are better than the initial conditions. This is because students are new and unfamiliar with the new methods applied in the teaching and learning process.

c. Reflection Stage

In this stage the writer reflexes together with the school subject teacher consortium (MGMPS) team of Indonesian History of Surabaya 12 Vocational High School in the teacher's room after class learning is complete. In this reflection we conclude that the implementation of teaching and learning activities takes place as follows: The teacher is not maximal in motivating students and Submit the subject matter and the teacher is not right in managing time. The implementation of teaching and learning activities in the first cycle is still lacking, so there needs to be improvement in the next cycle.

\section{Second cycle}

a. Planning Phase

At this stage the researcher is in conjunction with the school subject teacher consortium (MGMPS) team Indonesian History of Surabaya 12 Vocational High School prepares learning devices consisting of the learning implementation plan (RPP) 2, formative test questions 2, observation sheets, student chest numbers, and supporting teaching tools.

\section{b. Action and Observation Stage}

The implementation of learning activities for cycles II was held in the X Multi Media 3 class with a total of 35 students. In this case the researcher acts as the teaching teacher while the other teachers who join in the school subject teacher consortium (MGMPS) team Indonesian History Surabaya 12 Vocational High School act as observers. The teaching and learning process refers to the lesson plan by paying attention to the revisions in the first cycle so that errors or shortcomings in the first cycle do not recur in the second cycle. Observation is carried out simultaneously with the implementation of teaching and learning.

This stage is carried out in 3 parts, namely opening, core, and closing. In the opening section, the researcher explains the learning objectives, then explains the learning methods that will be carried out that day, and apperception. In the Core section the researcher explained the outline of the material by displaying power points on the LCD screen, which was about the PRRI rebellion, PERMESTA, and Andi Azis rebellion. Then the researcher explained the stages of the Team Quiz Plus method as in the first cycle. 
After all the students understood the procedures for the Team Quiz Plus, the Team Quiz game was soon completed. The researcher as the teaching teacher guides the quiz in front, while the observer observes the activities of the students in the group. Students are divided into 7 groups, each group consisting of 5 students.

Table 4. The Results of The Observations

\begin{tabular}{|c|c|c|c|c|c|}
\hline No. & Group name & Assessment Aspect & Well & Enough & Less \\
\hline 1 & Sumatra & $\begin{array}{l}\text { 1. Cooperation } \\
\text { 2. Sportsmanship } \\
\text { 3. Never give up } \\
\text { 4. Accuracy of answers }\end{array}$ & $\begin{array}{l}\mathrm{V} \\
\mathrm{V} \\
\mathrm{V} \\
\mathrm{V}\end{array}$ & & \\
\hline 2 & Java & $\begin{array}{l}\text { 1. Cooperation } \\
\text { 2. Sportsmanship } \\
\text { 3. Never give up } \\
\text { 4. Accuracy of answers }\end{array}$ & & $\begin{array}{l}\mathrm{V} \\
\mathrm{V} \\
\mathrm{V} \\
\mathrm{V}\end{array}$ & \\
\hline 3 & Borneo & $\begin{array}{l}\text { 1. Cooperation } \\
\text { 2. Sportsmanship } \\
\text { 3. Never give up } \\
\text { 4. Accuracy of Answers }\end{array}$ & $\begin{array}{l}\mathrm{V} \\
\mathrm{V} \\
\mathrm{V} \\
\mathrm{V}\end{array}$ & & \\
\hline 4 & Sulawesi & $\begin{array}{l}\text { 1. Cooperation } \\
\text { 2. Sportsmanship } \\
\text { 3. Never give up } \\
\text { 4. Accuracy of answers }\end{array}$ & $\begin{array}{l}\mathrm{V} \\
\mathrm{V} \\
\mathrm{V} \\
\mathrm{V}\end{array}$ & & \\
\hline 5 & Bali & $\begin{array}{l}\text { 1. Cooperation } \\
\text { 2. Sportsmanship } \\
\text { 3. Never give up } \\
\text { 4. Accuracy of answers }\end{array}$ & $\begin{array}{l}\mathrm{V} \\
\mathrm{V} \\
\mathrm{V} \\
\mathrm{V}\end{array}$ & & \\
\hline 6 & Maluku & $\begin{array}{l}\text { 1. Cooperation } \\
\text { 2. Sportsmanship } \\
\text { 3. Never give up } \\
\text { 4. Accuracy of answers }\end{array}$ & $\begin{array}{l}\mathrm{V} \\
\mathrm{V} \\
\mathrm{V} \\
\mathrm{V}\end{array}$ & & \\
\hline 7 & Papua & $\begin{array}{l}\text { 1. Cooperation } \\
\text { 2. Sportsmanship } \\
\text { 3. Never give up } \\
\text { 4. Accuracy of answers }\end{array}$ & & $\begin{array}{l}\mathrm{V} \\
\mathrm{V} \\
\mathrm{V} \\
\mathrm{V}\end{array}$ & \\
\hline
\end{tabular}

From the table of observations made by the observers, it can be seen that there are 5 groups whose learning activities are good, and there are 2 groups whose activities have not been good. Means there has been an increase compared to the first cycle.

At the end of the teaching and learning process students are given a formative test II with the aim of knowing the level of success of students in the teaching and learning process that has been carried out. The instrument used was a formative test II. The data from the research results in the second cycle are as follows.

Table 5. Formative Test Values in Cycle II

\begin{tabular}{|c|c|c|c|c|c|c|c|}
\hline \multirow{2}{*}{ No. } & \multirow{2}{*}{ Value } & \multicolumn{2}{|c|}{ Information } & \multirow{2}{*}{ No. } & \multirow{2}{*}{ Value } & \multicolumn{2}{|c|}{ Information } \\
\cline { 7 - 9 } & & $\mathrm{T}$ & $\mathrm{TT}$ & & & $\mathrm{T}$ & TT \\
\hline 1 & 90 & $\sqrt{ }$ & & 19 & 80 & $\sqrt{ }$ & \\
\hline 2 & 70 & & $\sqrt{ }$ & 20 & 60 & & $\sqrt{ }$ \\
\hline 3 & 75 & $\sqrt{ }$ & & 21 & 80 & $\sqrt{ }$ & \\
\hline 4 & 75 & $\sqrt{ }$ & & 22 & 80 & $\sqrt{ }$ & \\
\hline 5 & 75 & $\sqrt{n n n n n y y y}$ & & 23 & 80 & $\sqrt{ }$ & \\
\hline 6 & 70 & & $\sqrt{ }$ & 24 & 75 & $\sqrt{ }$ & \\
\hline
\end{tabular}




\begin{tabular}{|c|c|c|c|c|c|c|c|}
\hline 7 & 75 & $\sqrt{ }$ & & 25 & 70 & & $\sqrt{ }$ \\
\hline 8 & 60 & & $\sqrt{ }$ & 26 & 90 & $\sqrt{ }$ & \\
\hline 9 & 75 & $\sqrt{ }$ & & 27 & 80 & $\sqrt{ }$ & \\
\hline 10 & 80 & $\sqrt{ }$ & & 28 & 60 & & $\sqrt{ }$ \\
\hline 11 & 80 & $\sqrt{ }$ & & 29 & 80 & $\sqrt{ }$ & \\
\hline 12 & 75 & $\sqrt{ }$ & & 30 & 60 & & $\sqrt{ }$ \\
\hline 13 & 75 & $\sqrt{ }$ & & 31 & 80 & $\sqrt{ }$ & \\
\hline 14 & 75 & $\sqrt{ }$ & & 32 & 75 & $\sqrt{ }$ & \\
\hline 15 & 75 & $\sqrt{ }$ & 33 & 70 & & $\sqrt{ }$ \\
\hline 16 & 90 & $\sqrt{ }$ & 34 & 60 & & $\sqrt{ }$ \\
\hline 17 & 80 & $\sqrt{ }$ & & 35 & 80 & $\sqrt{ }$ & \\
\hline 18 & 90 & $\sqrt{ }$ & & & & \\
\hline
\end{tabular}

Table 6. Recapitulation of Formative Test Results of Students in Cycle II

\begin{tabular}{|l|l|c|}
\hline No. & Description & $\begin{array}{l}\text { Cycle II } \\
\text { Results }\end{array}$ \\
\hline 1 & The average formative test value & 74.28 \\
2 & Number of students who complete study & 26 \\
3 & Percentage of learning completeness & $74.28 \%$ \\
\hline
\end{tabular}

From the table above, the average score of student pre- learning is 74.28 and learning completeness reaches $74.28 \%$ or there are 26 students from 35 students who have finished learning. These results indicate that in this second cycle classical mastery learning has improved slightly better than cycle I. The increase in student learning outcomes is because the teacher is more able to motivate students who are less capable in the subjects they study.

\section{c. Reflection Stage}

In this reflection we conclude that there are still shortcomings in learning activities, namely: (1) Teachers have not been optimal in motivating students. (2) The teacher has not been maximal in guiding students to form conclusions / find conclusions.

The implementation of learning activities in the second cycle still has shortcomings. Then there needs to be a follow up in the form of improvements to be carried out in cycle III, among others: (1) Teachers in motivating students should be able to make students more motivated during the teaching and learning process takes place. (2) Teachers must be more friendly with students so that there is no fear in students either to answer quiz questions. (3) Teachers must be more patient in guiding students to form conclusions / find concepts.

\section{Third cycle}

a. Planning Phase

At this stage the researcher prepares learning devices consisting of lesson plans 3, formative test questions 3, observation sheets, student chest numbers, and supporting teaching tools. 
b. Action and Observation Stage

The implementation of teaching and learning activities for the third cycle was held in the X Multi Media 3 class with a total of 35 students. In this case the researcher acts as the teaching teacher while the other History teachers act as observers. The teaching and learning process refers to the lesson plan by paying attention to the revisions in the second cycle, so that errors or shortcomings in the second cycle are not repeated again in cycle III. Observation is carried out simultaneously with the implementation of teaching and learning

This stage is carried out in 3 parts, namely opening, core, and closing. In the opening section, the researcher explains the learning objectives, then explains the learning methods that will be carried out that day, and apperception and motivation. In the Core section the researcher explained the outline of the material by displaying power points on the LCD screen about the RMS and G $30 \mathrm{~S} / \mathrm{PKI}$ rebellions. Then the researcher explained the stages of the Team Quiz Plus method as in the previous cycle.

After all students understand the procedures of the Team Quiz Plus, the game of Team Quiz Plus is soon completed. The researcher as the teaching teacher guides the quiz in front, while the observer observes the activities of the students in the group. Students are divided into 7 groups. Each group has 5 members.

Table 7. The Results of The Observations

\begin{tabular}{|c|c|c|c|c|c|}
\hline No. & Group name & Assessment Aspect & Well & Enough & Less \\
\hline 1 & Sumatra & $\begin{array}{l}\text { 1. Cooperation } \\
\text { 2. Sportsmanship } \\
\text { 3. Never give up } \\
\text { 4. Accuracy of answers }\end{array}$ & $\begin{array}{l}\mathrm{V} \\
\mathrm{V} \\
\mathrm{V} \\
\mathrm{V}\end{array}$ & & \\
\hline 2 & Java & $\begin{array}{l}\text { 1. Cooperation } \\
\text { 2. Sportsmanship } \\
\text { 3. Never give up } \\
\text { 4. Accuracy of answers }\end{array}$ & $\begin{array}{l}\mathrm{V} \\
\mathrm{V} \\
\mathrm{V} \\
\mathrm{V}\end{array}$ & & \\
\hline 3 & Borneo & $\begin{array}{l}\text { 1. Cooperation } \\
\text { 2. Sportsmanship } \\
\text { 3. Never give up } \\
\text { 4. Accuracy of answers }\end{array}$ & $\begin{array}{l}\mathrm{V} \\
\mathrm{V} \\
\mathrm{V} \\
\mathrm{V}\end{array}$ & & \\
\hline 4 & Sulawesi & $\begin{array}{l}\text { 1. Cooperation } \\
\text { 2. Sportsmanship } \\
\text { 3. Never give up } \\
\text { 4. Accuracy of answers }\end{array}$ & $\begin{array}{l}\mathrm{V} \\
\mathrm{V} \\
\mathrm{V} \\
\mathrm{V}\end{array}$ & & \\
\hline 5 & Bali & $\begin{array}{l}\text { 1. Cooperation } \\
\text { 2. Sportsmanship } \\
\text { 3. Never give up } \\
\text { 4. Accuracy of answers }\end{array}$ & $\begin{array}{l}\mathrm{V} \\
\mathrm{V} \\
\mathrm{V} \\
\mathrm{V}\end{array}$ & & \\
\hline 6 & Maluku & $\begin{array}{l}\text { 1. Cooperation } \\
\text { 2. Sportsmanship } \\
\text { 3. Never give up } \\
\text { 4. Accuracy of answers }\end{array}$ & $\begin{array}{l}\mathrm{V} \\
\mathrm{V} \\
\mathrm{V} \\
\mathrm{V}\end{array}$ & & \\
\hline 7 & Papua & $\begin{array}{l}\text { 1. Cooperation } \\
\text { 2. Sportsmanship } \\
\text { 3. Never give up } \\
\text { 4. Accuracy of answers }\end{array}$ & $\begin{array}{l}\mathrm{V} \\
\mathrm{V} \\
\mathrm{V} \\
\mathrm{V}\end{array}$ & & \\
\hline
\end{tabular}

From the observation results table above can be seen that all group learning activities are good, all active, enthusiastic, passion, in prose s learning. 
At the end of the teaching and learning process students are given a formative test III with the aim to determine the level of student achievement in the learning process . The instrument used was a formative test III. The research data on Cycle III are as follows:

Table 8. Formative Test Values in Cycle III

\begin{tabular}{|c|c|c|c|c|c|c|c|}
\hline \multirow{2}{*}{ No. } & \multirow{2}{*}{ Value } & \multicolumn{2}{|c|}{ Iformation } & \multirow{2}{*}{ No. } & \multirow{2}{*}{ Value } & \multicolumn{2}{|c|}{ Information } \\
\hline & & $\mathrm{T}$ & TT & & & $\mathrm{T}$ & TT \\
\hline 1 & 90 & $\sqrt{ }$ & & 19 & 100 & $\sqrt{ }$ & \\
\hline 2 & 90 & $\sqrt{ }$ & & 20 & 90 & $\sqrt{ }$ & \\
\hline 3 & 100 & $\sqrt{ }$ & & 21 & 80 & $\sqrt{ }$ & \\
\hline 4 & 70 & & $\sqrt{ }$ & 22 & 85 & $\sqrt{ }$ & \\
\hline 5 & 90 & $\sqrt{1}$ & & 23 & 80 & $\sqrt{ }$ & \\
\hline 6 & 90 & $\sqrt{ }$ & & 24 & 80 & $\sqrt{ }$ & \\
\hline 7 & 80 & $\sqrt{ }$ & & 25 & 85 & $\sqrt{ }$ & \\
\hline 8 & 70 & & $\sqrt{ }$ & 26 & 90 & $\sqrt{ }$ & \\
\hline 9 & 90 & $\sqrt{ }$ & & 27 & 80 & $\sqrt{ }$ & \\
\hline 10 & 90 & $\sqrt{ }$ & & 28 & 90 & $\sqrt{ }$ & \\
\hline 11 & 85 & $\sqrt{ }$ & & 29 & 80 & $\sqrt{ }$ & \\
\hline 12 & 80 & $\sqrt{ }$ & & 30 & 80 & $\sqrt{ }$ & \\
\hline 13 & 90 & $\sqrt{ }$ & & 31 & 90 & $\sqrt{ }$ & \\
\hline 14 & 90 & $\sqrt{ }$ & & 32 & 90 & $\sqrt{ }$ & \\
\hline 15 & 70 & & $\sqrt{ }$ & 33 & 85 & $\sqrt{ }$ & \\
\hline 16 & 100 & $\sqrt{ }$ & & 34 & 90 & $\sqrt{ }$ & \\
\hline 17 & 90 & $\sqrt{ }$ & & 35 & 100 & $\sqrt{ }$ & \\
\hline 18 & 90 & $\sqrt{ }$ & & & & & \\
\hline total & 1555 & 15 & 3 & total & 1475 & 17 & 0 \\
\hline
\end{tabular}

Table 9. Recapitulation of Formative Test Results of Students in Cycle III

\begin{tabular}{|l|l|c|}
\hline No. & Description & Cycle III Results \\
\hline 1 & The average formative test value & 86.57 \\
2 & Number of students who complete study & 32 \\
3 & Percentage of learning completeness & $86.57 \%$ \\
\hline
\end{tabular}

Based on the above table that the value of $\mathrm{r}$ verage formative tests amounted to 86.57 and from 35 students who have completed a total of 32 students and three students have not reached mastery learning. Then classically the learning completeness that has been achieved is $86.57 \%$ (including complete categories). The results in this third cycle have improved better than the second cycle. The increase in learning outcomes in the third cycle is influenced by an increase in the ability of students to learn the subject matter that has been applied so far and there is a hard effort of teachers to motivate students and set the right time so that all students get attention, especially students who are less able to understand the lesson.

\section{c. Reflection Stage}

In this reflection we examine what has been done well and which is still not good in the learning process by using the Team Quiz Plus method. From the data that we have obtained can be accomplished as follows: (1) During the teaching and learning 
process the teacher has carried out all the learning well. Although there are some aspects that are not perfect, the percentage of implementation for each aspect is quite large. (2) Based on observational data it is known that students are active during the learning process. (3) Weaknesses in the previous cycles have experienced improvements and improvements to make it better. (4) Student learning outcomes in cycle III achieve completeness.

In cycle III the teacher has implemented the Team Quiz Plus method well and seen from the activities of the students and the learning outcomes of students implementing the teaching and learning process has gone well. So there is no need for too many revisions, but what needs to be considered for the next action is to maximize and maintain what has been done with the aim that the learning objectives can be achieved.

\section{CONCLUSIONS}

Based on the analysis of observational data, it can be seen that in the first cycle there were only 2 groups whose learning activities were good, while the other 5 groups were not good. In the second cycle there was an increase, there were 5 groups whose activities were good, and only 2 groups that were not good. In the third cycle, the learning activities of all groups were good. This means it can be concluded that the use of methods Team Quiz Plus, teachers have been able to increase the activity of students in the leraning process. This has a positive impact on increasing student learning outcomes.

The results of this research show that learning using the Team Quiz Plus method can improve the learning achievement of Indonesian History in $\mathrm{X}$ Multi Media 3 students in the even semester of the 2018-2019 academic year on the material: "The Efforts of the Indonesian Nation to Face National Disintegration ". This can be seen from the increase in the average value of students formative tests, namely: 70.0 (cycle 1), 74.28 (cycle 2), and 86.57 (cycle 3). This study also showed that learning Indonesian history using Team Quiz Plus method can enhance their understanding and mastery of students to the material that submitted by teachers so that mastery learning students increased (mastery learning increased from I, II, and III cycles) are respectively $70.0 \%, 74.28 \%$, and $86,57 \%$. In the third cycle the completeness of student learning has been achieved classically.

\section{REFERENCES}

Arikunto, Suharsimi. 1993. Humane Teaching Management. Jakarta: Rineka Cipta.

Dimyati and Mudjiono (1999). Learning and Learning . Jakarta: Rineka Cipta.

Mukhlis, Abdul.(Ed). 2000. Classroom Action Research. Paper Committee for Scientific Writing Training for Teachers in Tuban District.

Poerwodarminto. 1995. Large Indonesian Dictionary. Jakarta: Developing Science.

Compiler, Team. 1989. East Java Teacher Education School Book. Surabaya: Ministry of Education and Culture

Supriyono, Agus. 2012. Cooperative Learning. Yogyakarta: Student Library. Sumadi. 1989. Educational Psychology. Yogyakarta: Andi Offset.

Silberman, M. 2007. Active Learning: 101 Strategies to Teach Any Subject. Toronto: Allyn Bacon 